\title{
THE SOVIET CONCEPT OF PEACEFUL COEXISTENCE AND ITS IMPLICATIONS FOR INTERNATIONAL LAW
}

\author{
VICTOR P. KARPOV*
}

I

\section{Peaceful Coexistence and Soviet Foreign Policy}

The concept of peaceful coexistence has always been the general line of Soviet foreign policy. Of course, this concept has been liable to some development and improvement but its very emergence was a result of the Great October Revolution which gave birth to the socialist system.

From its very inception the Soviet state proclaimed peaceful coexistence as the basic principle of its foreign policy. The fact that the very first political act of the Soviet Russia was the Decree on Peace, the decree on stopping the bloody war, is not to be considered an accident.

The peaceful coexistence policy is not a tactical move on the part of the Soviet Union. Our desire for peace and peaceful coexistence springs from the very nature of our socialist society in which there are no social groups interested in profiting by means of war or by the arms race.

Moreover, the principle of peaceful coexistence is the only realistic policy to pursue nowadays when the world consists of nations belonging to different social systems-capitalism and socialism. In view of the present alignment of forces in the world and of the progress of military technique, it is impossible to find any other sound basis for relations between countries except that of peaceful coexistence. We cannot even discuss this principle in terms whether we should "accept" or "reject" it. The point is that today peaceful coexistence is an indisputable fact of international life and not someone's request or suggestion. Peaceful coexistence is an objective necessity stemming from the contemporary stage of the development of human society.

If we face facts squarely, we should admit that the essence of world politics now is the character of relations between the two main socioeconomic systems-capitalism and socialism. And capitalist and socialist countries exist side by side on our planet. The rise of socialism was an inevitable objective historical development. However, the capitalist world refused to recognize this fact and has repeatedly resorted to war to destroy its unwelcome neighbor. It is common knowledge that all these attempts have turned out to be futile.

The attempts to solve differences between the two systems by means of war have always been costly for the common people. They resulted in millions of killed and

- First Secretary, Embassy of the Union of Soviet Socialist Republics, Washington, D.C. 
wounded, in thousands of destroyed towns and villages, and in senseless losses of human energy and ingenuity.

And now the very character of modern nuclear warfare makes planning for war as a means of settling differences between the two systems obvious insanity. None of these systems can rely upon war to secure its victory over the other. The Soviet Union does not need any war to secure victory over capitalism, although the Soviet people believe in such a victory.

It is not war that should settle the controversy between the two systems. In the final analysis, it will not be the system which produces the greatest quantity of means of destruction that will triumph, but the system which produces the most of material and spiritual values, which provides man with a better life. We are absolutely sure that one cannot drive people to paradise with a club, or drive them to communism by means of war.

Communists do not conceal from anyone their desire to attract all people of the world to the side of socialism. This is regarded by them as their prime international task. But the question is: by what means is that cause to be advanced? We are not going to attain it by unleashing wars, nor by forcing our way of life on other nations. It is through creative labor, through the great constructive force of the liberated peoples, through the revolutionary energy of the working people, that we are going to raise the prestige of socialism and to win it more and more support on the part of various nations.

Some people say that communism promotes the cause of peaceful coexistence because this favors communism and brings it certain advantage. These people are right. Peaceful coexistence, we feel, really favors our cause, the cause of socialism. And we do not conceal our belief that, in the long run, peaceful competition between socialism and capitalism will result in an overall victory for socialism.

But that would be a fair competition-a competition in the best possible satisfaction of all man's needs. Why should nations be afraid of that kind of competition? If they are sure that their cause is right, they should wholeheartedly accept this competition and do their best to win it. And if there are countries reluctant to be engaged in peaceful economic competition with the socialist countries one can but suggest that they rely more on their arms and armies in competition with socialism than on their productive capacities.

Coexistence is a continuation of the struggle between the two social systems, but struggle by peaceful means, without resort to war, without interference by one state in the internal affairs of another. It is a competition in peaceful endeavors. It implies reciprocal concessions and compromises-I would say mutual adaptation-in the sphere of interstate relations as regards the settlement of urgent practical issues in order to preserve and strengthen peace.

The point at issue now is not whether or not there should be peaceful coexistence. In fact, since socialism and capitalism are not at war they are in practice coexisting. And if we want to avoid the lunacy of world nuclear war we 
should coexist. The only alternative we have nowadays is between peaceful coexistence and nuclear holocaust. There are no other choices.

But the point is that we should coexist on a reasonable basis.

There are some people in the West who willy-nilly accept the necessity to coexist with the Soviet Union because, although it belongs to another social system, it is a powerful nation and possesses mighty weapons. But as soon as a question arises of peaceful coexistence between a big Western power and a smaller country, these people prefer methods of coercion-economic, political and even military threats. That, of course, is a wrong attitude; and it can bring about very grave consequences.

The principle of peaceful coexistence should be universal. It should be based on the assumption that every country, big or small, chooses for itself or borrows from its neighbors what it thinks fit, without any outside imposition. This is a precondition, the only one that can make coexistence genuinely peaceful and goodneighborly.

In short, coexistence on a reasonable basis presupposes the recognition of the existence of different social systems, the recognition of the right of every people to deal independently with all political and social problems of its own country, respect for the sovereignty of other nations, adherence to the principle of noninteference in internal affairs of other countries, and the settlement of all international issues by negotiation.

Thus, the Soviet view of peaceful coexistence of countries with different social and political systems does not simply imply an absence of war or a state of temporary and unstable armistice. It provides for the maintenance of friendly economic and political relations and envisages the establishment and development of a variety of forms of peaceful international cooperation.

And we believe that the realization of the Soviet proposals for general and complete disarmament under strict international control, the immediate and final abolition of the disgraceful colonial system, the conclusion of a German peace treaty, and the normalization on its basis of the situation in West Berlin would remove the chief causes of existing international tensions, destroy the very machinery of war, and enable all peoples to go calmly about their peaceful and creative labor.

II

\section{Peaceful Coexistence and International Law}

The principle of peaceful coexistence is more and more widely adhered to by states in their international relations. It has won not only the widest moral support on the part of the peoples, but also international legal recognition. The countries of the socialist camp are guided precisely by this principle in their relations with other countries.

The principle of peaceful coexistence is reflected in the decisions of the Bandung Conference of Asian and African countries. Many countries of Europe, Asia, 
and Africa have solemnly proclaimed it as the basis of their foreign policy. And this idea was more than once unanimously supported in the resolutions of the United Nations General Assembly (for instance, decisions of 12th, I3th and subsequent sessions). It is very significant that the I7th session of the General Assembly unanimously resolved on December 18,1962 , to undertake further studies to promote and codify international legal principles of friendly relations and cooperation between states.

If we have a look at the United Nations Charter itself we can find out that it is based on the principle of peaceful coexistence although it does not use this very word. In its Preamble, the United Nations Charter, for example, states that the member countries undertake "to practice tolerance and live together in peace with one another as good neighbors," and to unite their "strength to maintain international peace and security." By that, the U.N. Charter in fact provides for the practice of what we call peaceful coexistence. Some other articles of the U.N. Charter are also based on a tacit recognition of this principle, and also on the recognition of such principles as the sovereign equality of states (Article 2(I)), non-intervention (Article 2(7)), the equality and self-determination of peoples (Article I(2)), territorial integrity (Article 2(4)), and so on.

The well-known clause providing for unanimity of the permanent members of the Security Council when major decisions are to be taken is also a reflection of the principle of coexistence. In fact, if this clause had not been included into the U.N. Charter, we might have witnessed situations when a group of nations representing one social system would have tried to impose its will on another nation or other nations representing a different social system. Such a hypothetical situation would have led inevitably to complete disregard of principle of peaceful coexistence of states with different social systems and cannot but lead to the violation of the goals of the United Nations and to a dangerous aggravation of international tension.

The majority rule cannot be applied to the relations between different social systems. Such relations are inevitably to be based on mutual respect for the sovereign equality of nations, peaceful negotiation, and reasonable compromise.

That is why we consider very dangerous all attempts to change the U.N. Charter so that the unanimity rule in the Security Council is abolished. This could lead only to the collapse of the United Nations. In this connection I would like to mention the case of so-called Soviet "failure" to pay for the U.N. operations in the Middle East and in the Congo: to mention it because some governments try to resolve the financial crisis of the United Nations at the expense of the Soviet Union by using methods which run absolutely counter to the principles of international law if this law is understood properly.

This is the essence of the case: Attempts are being made to apply Article ig of the U.N. Charter to the question of reimbursement of the expenditures incurred by U.N. operations in the Middle East and the Congo. But Article xg has nothing 
to do with these cases; it can be applied only to the arrears in members' payments to the regular budget. Decisions on reimbursement for the expenditures for the Middle East and Congo operations were adopted by the General Assembly, bypassing the Security Council and usurping the rights of the Security Council against the clear provisions of the Charter. (According to the Charter, the General Assembly makes recommendations that are not obligatory for those countries which did not vote for them.)

The same goes for the decisions of the International Court of Justice which is being used to prove the alleged legality of this illegal attempt. ${ }^{1}$ Incidentally, the United States does not recognize that decisions of the International Court of Justice are obligatory in all cases, and has made a reservation to this effect while ratifying the Statute of the Court. ${ }^{2}$

The Soviet Union's position in this case is clear. We feel that the responsibility for the consequences of aggression, including financial implications, should be borne by those who have committed the acts of aggression. Any other approach would only encourage aggressors. It is primarily and precisely for this reason that the Soviet Union is not sharing, and will not share, the expenditures for the U.N. operations in the Middle East and the Congo.

We are not going to change our position under any pressure. Our position is just, and we are not inclined to compromise it. On March 2I of this year, the Soviet government issued a warning that in case of any attempt to act along the mentioned unlawful lines, the Soviet Union may be obliged to reconsider its attitude toward the U.N. activities in general.

A theoretical basis, so to say, of the attempts to make the U.S.S.R. pay for those U.N. emergency operations can be easily found in the concepts which claim that international law should prevail over the national or municipal law. This attitude is completely alien to the principle of peaceful coexistence, as it entails an encroachment upon the sovereign rights of nations and opens avenues for interference into their domestic affairs.

The same goes for the proposal to grant obligatory jurisdiction to the International Court of Justice, which some American lawyers view as one of the ways to improve the "rule of law" in international relations. This is not only contrary to the spirit of peaceful coexistence but at the same time is not adequate in present circumstances. The most burning international issues, such as the liquidation of colonial system or the solution of the West Berlin question, are political problems first of all, and cannot be solved by a court or an arbitration alone.

These are, broadly speaking, the main prerequisites that should ensure the application of the principle of peaceful coexistence to international law.

\footnotetext{
${ }^{1}$ Certain Expenses of the United Nations (Art. 17, para. 2, of the Charter), [1962] I.C.J. Rep. I5I.

${ }^{2}$ Declaration of August 26, I946, 6r Stat. I218.
} 


\section{III}

The Basic Principles of Peaceful Coexistence

Speaking more specifically, we can trace the following, more detailed provisions which constitute the essence of the peaceful coexistence and which, in our understanding, should be reflected in the international law.

r. Renunciation of war as means of settling international disputes, and their solution by negotiation.

Compliance with this principle should lead to adoption of specific measures that would exclude war from the life of human society both by way of solemn obligations of states and by measures of physical disarmament that would liquidate all means of waging war. To achieve this goal, the Soviet government proposes the general and complete disarmament program, various measures of partial disarmament, and a non-aggression pact between the NATO and Warsaw Pact countries. Recently the Soviet government advanced a new program to this effect, which provides for an international agreement to renounce the use or threat of force in territorial and border disputes between nations. This agreement should include the following provisions:

(a) a solemn undertaking not to.resort to force to alter existing borders;

(b) the acknowledgment that the territories of states should not, even temporarily, be the object of any invasion, attack, military occupation, or any other forcible measure directly or indirectly undertaken by other states for whatever political, economic, strategic, border or any other considerations;

(c) a firm statement that neither differences in social and state systems, nor refusal to grant recognition or absence of diplomatic relations, nor any other pretext may serve as a basis for the violation by one state of the territorial integrity of another;

(d) a commitment to solve all territorial disputes by peaceful means in conformity with the United Nations Charter.

2. Equality, mutual understanding and trust between countries.

3. Consideration for each other's interests.

4. Non-interference in internal affairs of other countries.

5. Recognition of the right of all peoples to solve all the problems of their countries by themselves. This should provide for all countries to refrain from "exporting" revolution or counter-revolution. Communists do believe that the idea of communism will ultimately triumph throughout the world, just as it triumphed already in the Soviet Union and in some other countries. But when we say that in competition with capitalism the socialist system will win, this does not signify by any means that we shall achieve that victory by interfering in the internal affairs of non-socialist countries. Our confidence in the victory of communism is based on a knowledge of the laws governing the development of human society. Just as in its time capitalism, as the more progressive system, took the place of 
feudalism, so will capitalism be inevitably replaced by the more progressive and just social system-communism.

6. Strict respect for the sovereignty and territorial integrity of all countrics. This principle should be strictly observed; and its observance is, of course, incompatible with some resolutions that have from time to time been adopted by the American Congress, as those calling for "liberation" of some integral parts of Soviet Union-of the Ukraine, Byelorussia, Lithuania, Latvia, Estonia, Armenia, Azerbaijan, Georgia, Kazakhstan, Turkmenistan and even some "Ural Area." I would say that this is roughly the same as if the parliament of Mexico, for example, would have passed a resolution demanding that Texas, Arizona, and California be "liberated from American slavery." Such an attitude, of course, is incompatible with the principle of peaceful coexistence and with international law in general.

7. Promotion of economic and cultural cooperation on the basis of complete equality and mutual benefit. This should lead to abolition of all forms of economic blockade, of economic sanctions, or trade discrimination.

\section{ConCLUSTON}

The Soviet Union has consistently pursued, and will pursue, the policy of peaceful coexistence of states with different social systems.

We are convinced that the principle of peaceful coexistence should be the basis of the whole structure of contemporary international law. Only if it is based on the principle of peaceful coexistence can the international law best promote the cause of peace and mutual understanding between nations. 